\title{
IMPLEMENTATION OF PTKIN QUALITY ANSURANCE : PERFORMANCE IMPROVEMENT EFFORTS THROUGH MOTIVATION AND JOB SATISFACTION IN ACEH
}

\author{
Yusaini $^{1}$, Darmawati ${ }^{2}$, Mahyiddin ${ }^{3}$, Zainuddin $^{4}$ \\ 1,3,4 Institut Agama Islam Negeri, Langsa \\ ${ }^{2}$ Universitas Muhammadiyah Sumatera Utara, Medan \\ yusaini@iainlangsa.ac.id \\ darmawati@umsu.ac.id \\ daudmahyiddin@gmail.com \\ zainuddin@iainlangsa.ac.id
}

\begin{abstract}
This article discusses the quality assurance performance of the Aceh State Islamic Religious College (PTKIN), which is influenced by motivation and job satisfaction in the implementation of quality assurance. This article describes three important things, namely describing the response of quality assurance implementers on motivation and job satisfaction, and proving quantitatively about the contribution of both to the quality assurance performance of PTKIN Aceh. Obtaining data through a survey questionnaire on motivation, job satisfaction and performance. Data analysis used descriptive analysis techniques to explain motivation responses and job satisfaction. Testing the performance hypothesis of PTKIN Aceh quality assurance using a simple regression test. The results of the analysis concluded that the motivation and job satisfaction of the Aceh PTKIN quality assurance implementers in implementing the quality assurance system was Strong or Good, and had a significant positive effect on the motivation and job satisfaction variables on the performance of the Aceh PTKIN quality assurance implementers.
\end{abstract}

Keywords: Work Motivation, Job Satisfaction, Performance, Quality Assurance, and PTKIN Aceh.

\begin{abstract}
ABSTRAK
Artikel ini membahas tentang kinerja penjaminan mutu Perguruan Tinggi Keagamaan Islam Negeri (PTKIN) Aceh, yang dipengaruhi oleh motivasi dan kepuasan kerja dalam implementasi penjaminan mutu. Artikel ini menjelaskan tentang tiga hal penting, yaitu mendeskripsikan respon pelaksana penjaminan mutu tentang motivasi dan kepuasan kerja, serta membuktikan secara kuantitatif tentang kontribusi keduanya terhadap kinerja penjaminan mutu PTKIN Aceh. Prerolehan Data melalui angket survey motivasi, kepuasan kerja dan kinerja. Analisis data menggunakan teknik analisis deskriptif untuk menjelaskan respon motivasi dan kepuasan kerja. Pengujian hipotesis kinerja penjaminan mutu PTKIN Aceh menggunakan uji regresi sederhana. Hasil analisis menyimpulkan bahwa motivasi dan kepuasan kerja pelaksana penjaminan mutu PTKIN Aceh dalam melaksanakansistem penjaminan mutu sudah Kuat atau Baik, serta memiliki pengaruh positif secara signifikan variable motivasi dan kepuasan kerja terhadap kinerja pelaksana penjaminan mutu PTKIN Aceh.
\end{abstract}

Kata Kunci: Motivasi Kerja, Kepuasan Kerja, Kinerja, Penjaminan Mutu, dan PTKIN Aceh 


\section{A. INTRODUCTION}

The implementation of quality assurance in tertiary institutions is increasingly sticking out in the academic atmosphere in Indonesia. The implementation of quality assurance exists due to pressure from regulations, both from the Ministry of Research and Technology and the Ministry of Religion of the Republic of Indonesia. The implementation of quality assurance is currently being felt warmly among the academic community of higher education, both at the national and international levels (Fitrah, Ruslan, and Hendra 2018). Quality assurance is the benchmark for higher education through an accreditation-based assessment system. This is because proving the quality of higher education nationally is still being pursued through the assessment system for accreditation of study programs and tertiary institutions (A Bacin 2017).

The higher education quality assurance system has been implemented by the government for the continuity and improvement of the quality of higher education. Based on Law No. 12 of 2012, explained that the quality assurance system in higher education must be evaluated through the Internal Quality Assurance System
(SPMI) and the External Quality Assurance System (SPME), whose output is known as College Accreditation and Study Program Accreditation (Presiden Republik Indonesia 2012). So that this activity will be escorted under the Quality Assurance Agency (LPM) at the IAIN and UIN levels as well as the Quality Assurance Center (P2M) at the STAIN level (Fitrah, Ruslan, and Hendra 2018). The work ability of LPM / P2M at PTKIN can be measured by performance. Therefore, the performance of the LPM / P2M team must be guaranteed first. So the performance of the higher education Quality Assurance team really needs to be taken seriously. Whether the team has been able to work well, is able to carry out tasks and functions effectively and efficiently (Bambang Sumardjoko 2010). The good performance of the quality assurance team is needed to carry out all higher education quality improvement programs. In essence, the performance of the quality assurance team must be guaranteed before the higher education quality assurance program is implemented.

Performance is the ability shown by someone in carrying out something or the task that is being done. The task that is carried 
out is the responsibility of individuals and institutions / institutions (Yusaini, 2018). Thus, performance is a variable that determines the implementation of various programs that have been planned at LPM PTKIN. Because if all LPM programs can be implemented, it will certainly have a significant effect onimproving the quality of PTKIN.

Quality assurance performance needs to be measured quantitatively, so as to provide an overview of whether the quality assurance performance obtained will be comparable to the assigned task (Gumiandar 2013). Quality assurance performance needs to get a real picture so as to provide confidence in the acceleration of the quality of PTKIN in the future. But the performance of quality assurance is born and is influenced by motivation and job satisfaction. So these two variables are also important points that will affect the performance of higher education quality assurance (Fitria, R. dan Adam Idris. 2014).

The important question is how the performance of the Aceh PTKIN quality assurance implementers so far in responding to government regulations with the set standards. So this article aims to explain three important things, namely: (1) the response of quality assurance implementers regarding work motivation in implementing the quality assurance system at PTKIN; (2) quality assurance response regarding job satisfaction in implementing the quality assurance system in PTKIN; (3) quality assurance response regarding performance in implementing the quality assurance system in PTKIN; (4) the positive influence of motivation and job satisfaction simultaneously on the performance of quality assurance at PTKIN in Aceh.

\section{B. LITERATURE REVIEW}

\section{Higher Education Quality Assurance}

\section{System}

The higher education quality assurance system is a system that must be designed to realize the ideals of national education among universities. Quality assurance of higher education institutions in Indonesia formally only started in 2003, starting with guidelines for higher education quality assurance. The thing that really triggers the quality assurance movement is the existence of an obligation for universities to implement a quality assurance system, in order to create competent graduates in their respective fields (Fitrah, Ruslan, and Hendra 2018).

The Quality Assurance System in State Islamic Religious Universities (PTKIN) 
becomes a formal center or institution approved by the Minister of Religion in the Organization and Governance of each Higher Education. There are two levels or versions based on the size of PTKIN, for example at the STAIN level it is named the Center for Quality Assurance (P2M) and at the IAIN and UIN levels it is named the Quality Assurance Institute.The implement and control the quality of higher education (Kementerian Agama R.I. 2015)

Quality assurance institutions in Higher Education play a role in planning, implementing, evaluating and controlling all academic activities that will be carried out every fiscal year. Therefore, LPM Higher Education must have a performance that is measurable enough to carry out the tasks assigned. When viewed by naked eye, the number of working hours of LPM implemented exceeds the number of working hours of civil servants that have been determined. This is because the number of documents and academic activities required at the current university development is very rapid (Basri, n.d.).

The Quality Assurance System in Higher Education is implemented in an organizational structure that has been determined by the Minister of Religion for each PTKIN. For example, at IAIN Langsa, it has been decided and determined that the Host System will be implemented by an institution called the Quality Assurance Institute. Based on the organizational structure and work procedures of the Langsa State Islamic Institute, where the LPM is determined, it consists of the Head of the LPM, the Secretary, the Head of the Audit Center of the Quality Standards Development Center; and Center for Audit and Quality Control (Kementerian Agama R.I. 2015).

In implementing the Internal Quality Assurance System, there may be various problems, especially the incompatibility of financial planning to budget in accordance with the established academic plan. There are also many universities that do not support each other between the financial planning and financial planning departments quality assurance system planning. The two run on different lines. This is a significant obstacle in improving the quality of higher education. For example, the lack of budget to enable the auditors of the Quality Assurance Agency to carry out internal audits. This is also faced by Gajah Mada University which is described in a journal of Education Management Accountability, concluding several obstacles, namely the lack of commitment from the 
leaders, the lack of auditors, the Internal Quality Assurance System is trapped into routine activities (Sulaiman and Wibowo 2016).

\section{Work Motivation Quality Assurance}

The word motivation comes from the Latin word "movere" which means "push or driving force". This motivation can be raised in humans, especially those as subordinates or followers. While the verb is a physical and mental activity in doing a job. In this regard, it can be said that motivation is a question of how to encourage subordinates to work passionately, so that they are willing to work hard by giving all their abilities and skills to realize organizational goals (Lumentut, Pantow, and Dkk 2017).

Motivation can be interpreted as encouragement, because it can be used as a reason for someone to do something. Motivation means a condition that can provide encouragement or can be a reason for someone to want to do an act or activity that takes place consciously and real. Motives are also mostly interpreted with the word encouragement. The urge or energy is a movement of the soul and body to act, so that the motive is a driving force that moves people to behave and in their actions they have a specific purpose (Ma'ruf and Fitri 2021).

Motivation in a person can be ascertained that a person will not move at all from where he is if he is not influenced by motivation. Likewise in the world of work, motivation plays an important role in efforts to achieve the goals of an organization, no matter how great the plans that have been made by management if the application process is carried out by people (employees) who lack or even do not have strong motivation, it will cause the plan not to be realized (Lumentut et al., 2017). It is often found that if people work with full motivation, then that person can work without knowing time and not feeling tired. Even after working to complete a job, feel a sense of satisfaction at the end of the job. This can happen in any type of work. For example, the results of a study by Bank Mandiri Padang employees, it was found that employee work motivation had an effect on job satisfaction (Ridho and Susanti 2019).

There is a lot of empirical evidence about the need for an analysis of the factors that influence work motivation and the goal is that the performance of quality assurance tools can excel. Quality assurance is the main performance that must be prioritized to carry 
out the progress of academic quality in higher education. Concluded in a journal about the results of his research as follows: there is a positive and significant contribution either partially or simultaneously variable leadership, organizational culture, lecturer competence, and achievement motivation to the role of lecturers in quality assurance in higher education. explained that leadership has a positive effect on work motivation. Likewise, organizational culture that occurs in an educational institution also affects work motivation. Even in the study it was found that the role and competence of lecturers can have an influence on work motivation of quality assurance (B Sumardjoko 2010)

3. Job Satisfaction at the Quality Assurance Agency

Job satisfaction is an attitude that exists in a person towards the work assigned to him is shown and compared with the number of awards received by workers and the amount they believe they should receive. Job satisfaction is an emotional attitude with feelings of pleasure and love for all the work done. Job satisfaction is a form of behavior / attitude of employees / staff towards a number of jobs that are their responsibility. (Nasution 2015).
Job satisfaction generated by each person or employee/tendik is different. Pleasant feelings in completing work do not come to a person easily or cannot be present systematically. But it comes based on various considerations by each of them in completing the work. Satisfaction is also present based on consideration of the proportion of work that must be completed as a responsibility. So the amount of work that must be completed is also a basic consideration so that the name job satisfaction is born. At the limits that exceed the limit, meaning that the number of jobs is very large and not commensurate with the awards given, then job satisfaction will easily fade. So that someone feels the opposite, feeling dissatisfied with various other feelings that go against job satisfaction. Feelings of work too forced, benefits that are not commensurate with the amount of work, and so on are feelings that are counter to job satisfaction (Amilin 2008)

An employee who feels dissatisfied with his job, He tends to show attitudes and behaviors that interfere with organizational performance, such as high turnover (in and out), low attendance rates, slow to complete work, often tell other people about his work. , can even come to a strike attitude. If the feeling of satisfaction with workers is higher, 
the attitudes and feelings of a person will be lower to leave the job that is his responsibility (Jati Ariati 2010).

There are several indicators that make up job satisfaction in the results of his research as follows: "Job satisfaction is an emotional state associated with pleasant or unpleasant feelings according to the perceptions and views of employees / staff". So that the indicators of job satisfaction in are: (1) the work itself; (2) salary or wages; (3) career opportunities; (5) working conditions; and (5) Colleagues". Thus, this indicator can be used as a form of satisfaction variable and can be used to measure job satisfaction in various institutions, organizations, and other work units (Fitria, R. dan Adam Idris. 2014)

\section{Quality Assurance Performance}

Performance is a variable that is often targeted by researchers and experts in the PTKIN environment. Therefore the word performance becomes serious to learn. When viewed from the origin of the word, the word performance (performance) comes from the word "to perform" which is given, with four possible meanings, namely doing, fulfilling or running something, carrying out a responsibility and doing something that someone expects (Marwan 2015)

Performance is a word that is often debated, often used as a research variable, and often used as a variable that various groups look for weak points to get improvements. What exactly is the definition and purpose of the performance. So that the word performance becomes something that is often considered by various groups. Performance is an important factor for public lecturers who are employed at Kopertis Region V Yogyakarta. Motivation, competence, and leadership are important to consider in explaining this performance. If lecturers have high motivation and competence and are supported by good leadership, they will be able to improve their performance. The work environment in this study has no effect on performance (Pramudyo 2010).

Performance needs to be studied carefully to get information about what factors influence it. So that the factors that affect performance can be studied about what are the forming indicators. In fact, many research results offer certain factors and indicators as forming performance. Of course all versions can be justified, because it is 
adapted to the conditions, place, culture and work environment of each.

Quality assurance performance is also influenced by other factors, such as job satisfaction and motivation. Job satisfaction gives an idea of how much a person likes his job. Job satisfaction is an affective or emotional response to various aspects of a person's job who is carrying out a task. Job satisfaction is not a unified whole concept. Because, a person can feel quite satisfied with one aspect of his job and feel less satisfied with one or several other aspects (Kreitner, R. 2014).

The performance of quality assurance members is not only influenced by job satisfaction alone, but there are other factors such as work motivation. Work motivation is a variable that is often studied from improving performance. This is confirmed by the definition by Robbin which suggests that motivation is the desire to do as a willingness to expend a high level of effort for organizational goals, which is conditioned by the ability of that effort to meet an individual need (Robbins, S.P. 2010).

\section{METHOD}

This research was conducted by following the type of Mix Method research, because in addition to testing the hypothesis, it also attempted to describe the research questions posed. The instrument used is a questionnaire, namely a quality assurance performance survey questionnaire, job satisfaction questionnaire and work motivation questionnaire. These three types of questionnaires were used as an instrument for collecting data and used a Likert scale scoring technique. Data collection is directed to lecturers of State Islamic Religious Universities (PTKIN) who have been designated as research samples from the population of all lecturers in the UIN ArRaniry Banda Aceh, IAIN Lhokseumawe, IAIN Takengon, IAIN Langsa, and STAIN Meulaboh. The results of data collection were analyzed using the Linear Regression statistical test to prove whether motivation and job satisfaction have an effect on and contribute to the performance of the PTKIN Aceh quality assurance system actors. The results of the data analysis also used descriptive statistical analysis with the approach of presenting tables and pie charts. Based on the results of the two types of data analysis carried out, it is used as the basis for drawing research conclusions.

\section{DISCUSSION}


The discussion of this article is based on the findings of research conducted by the Mix Method method which aims to reveal a causal relationship between the variables of job satisfaction, motivation, and quality assurance performance. Data were collected using survey techniques through questionnaires distributed to lecturers at PTKIN Aceh (Singarimbun, M. 1989). The questionnaire compiled is a closed type with five different choices on one continuum line, with a Likert scale model that has an interval scale with an answer score for each questionnaire (Mala and Munirah 2019). The scoring of the respondent's answer by the quality assurance implementer can be linked in the form of a statement or attitude support which is expressed in words through the questionnaire item options and can be scored as shown in the following table;

Table 1. Relation between Interval Scale and Delivery Score On Choice of Each Questionnaire Item

\begin{tabular}{ccc}
\hline Performance Figures & Category & Score \\
\hline $0 \%-20 \%$ & Never & 1 \\
$21 \%-49 \%$ & Rarely & 2 \\
$41 \%-60 \%$ & Sometimes & 3 \\
$61 \%-80 \%$ & Often & 4 \\
$81 \%-100 \%$ & Always & 5 \\
\hline
\end{tabular}

Source: Riduwan. Cara Menggunakan dan Memakai Path Analysis (Analisa Jalur).

Bandung: Alfabeta, 2012, p.20.

Collecting data using a questionnaire which first tested Vallidity and reliability. The data collection questionnaire consisted of a survey questionnaire on work motivation $\left(\mathrm{X}_{1}\right)$, job satisfaction $\left(\mathrm{X}_{2}\right)$ and performance $\left(\mathrm{X}_{3}\right)$ of the implementing members of the PTKIN quality assurance system. Furthermore, the data were analyzed through several stages, namely descriptive analysis, testing the requirements for statistical analysis, and testing the research hypothesis using pathway model analysis. With this method, we will provide an explanation in this article relating to the motivation response, satisfaction and performance of PYKIN quality assurance implementers in Aceh.

\section{Work Motivation Response Quality Assurance}

The response to the work motivation of the implementers of the PTKIN quality assurance system was surveyed through three 
indicators, namely Effort (Effort), knowing work goals and meeting life's needs. For each indicator, several items were developed through the WORK MOTIVATION

arrangement

of a

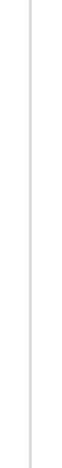

\section{$9,3.96 \quad 1,3.67$}

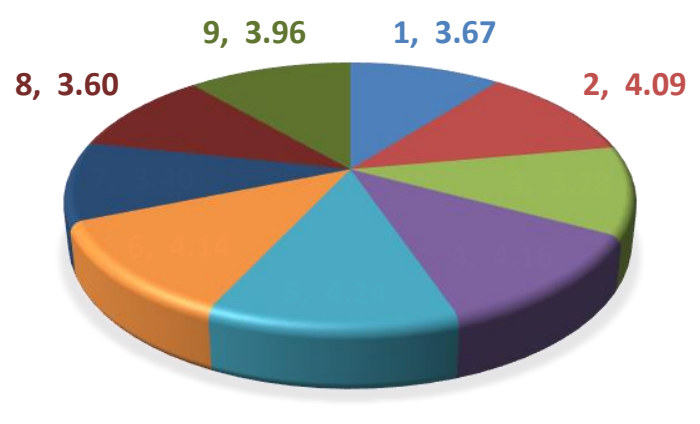

constructed by three questions, while the indicator for knowing the work objectives is formed by three questions and the indicators
回1

回2

43

-4

田5

46

田 7

-8

99 for meeting the needs are formed by three questions. The results of descriptive data analysis

questionnaire. For the Effort indicator it is can be illustrated by the following pie chart:

Figure 1. Comparison of Work Motivation Responses Implementing PTKIN PMS

The circle diagram according to Figure 1 , above is the result of an analysis of 9 (nine) 
question items on the work motivation variable, the nine questions on the work motivation variable are as follow;

1. The work that you are doing and have done often gets praise and appreciation from superiors.

2. Every job that is assigned, there is always a growing desire to complete it well and quickly.

3. In completing work, we do not know Tired.

4. You work carefully to get the job done.

5. You always work based on the goals you want to achieve.

6. The work that is completed is always accompanied by the goals and objectives to be achieved.

7. All the needs in completing work are obtained in an easy way.

8. The amount of work completed is proportional to the awards received.

9. The award you get gives a strong desire to work.

Based on Figure 1, it provides information that question number 1 about whether or not a quality assurance system implementer gets an award or praise after completing the work is responded to with an average score of 3.67. This score is the result of the average response that was responded to by 96 implementers of the PTKIN quality assurance system. The average score of 3.67 is the answer option score which states that these activities often occur in completing work. Thus this data provides information that the leadership often gives praise or appreciation to the implementers of the quality assurance system. This will have an impact on performance, and this is felt by the employees of BANK Sulselbar which is found through the results of research which concludes that giving motivation by the leadership will lead them to improve performance (Kurniawan 2012).

In question 2 (two) provides further information about the desire to complete each job properly and quickly. The information provided is based on the results of the analysis of the quality assurance system implementer's responses by giving an average score of 4.09 , this average score is at the option level or category always. This shows that the implementers of the quality assurance system at PTKIN. Often grows a sense of desire to get work done well and quickly. This feeling was a response from 96 implementers of the quality assurance system. Thus, it is illustrated to us that this 
feeling becomes working capital for the success of all academic activities at PTKIN.

The most encouraging thing next is the response about tirelessness at work. This provides information through the results of data analysis on the third question in the work motivation variable. The results of data analysis proved that the average score responded by the implementers of the quality assurance system was 3.78. This score informs that the implementers of the quality assurance system are often tireless in completing work. Usually this is evidenced by the existence of quality assurance system implementers who work hard, and still continue to work even after working hours.

The quality assurance (quality assurance) who is often also called the implementer of the quality assurance system, is required to be careful and thorough in their work. Based on the results of descriptive data analysis it was found that quality assurance in completing work is often carried out carefully. This is evidenced by the responses given through the questionnaire at an average score of 4.16. Quality assurance work with a conscientious nature is needed in the achievement of campus academic quality. Accuracy directs each work completion according to the expected goals. Even if the accuracy of quality assurance can be improved to an average score above 4.5 , the work to be completed is estimated to be able to improve academic quality as expected.

Visitors are required to be able to work on target with the stated goals. Many jobs are considered ineffective and inefficient because they are not done based on goals. Therefore, any work to be completed needs to be directed according to the expected goals.

The condition of the PTKIN quality assurance personnel when they are used to completing work by seeing the goals to be achieved. This awareness was revealed from the results of the analysis of the quality assurance response itself through a work motivation survey questionnaire which gave an average score of 4.24 . This score provides meaning and information to us that quality assurance in running a quality assurance system often works by looking at the work program objectives to be achieved. This is an encouraging result. Because words can often be interpreted as familiar. Accustomed to what is meant is quality assurance in completing a program is used to seeing the goals to be achieved. So that the work completion process will be directed according to the goal. 
Working according to program objectives is very necessary in completing a job. Therefore, the work program needs to be planned with great preparation. Quality assurance system will be felt if the entire work program is prepared through careful planning. One of the program preparations can be felt when quality assurance prepares the work program TOR. In the TOR has designed or stated the objective of completing the work program. So that the work will be completed according to the specified goals and time, the work that is felt is to make something. The implementer of the PTKIN quality assurance system is currently preparing each work program by setting goals and objectives to be achieved. According to the recognition of PTKIN quality assurance, giving its responses through a questionnaire is a work program that has been prepared often equipped with goals and objectives to be achieved. This is evidenced by the quality assurance response score of 4.14, and it becomes one information that work programs that become work plans every year are often accompanied by program goals and objectives.

Completing a work program can sometimes be difficult. The difficulties experienced are caused by many obstacles.
We understand together that a smooth work process will lead to success. However, a fast and successful work process needs to be supported by all work needs. The need for work tools or office equipment is absolutely necessary. For example, the need for computers, printers, scanners, and other office equipment will become a barrier to work if they are not met in completing work. The need for work guidelines, such as strategic planning, quality assurance workload (BKD) guidelines, performance guidelines, ortaker, candy and so on, becomes a ready-to-serve need if needed. So this need is expected not to become an obstacle in completing a job.

The quality assurance system of PTKIN's quality assurance system is currently experiencing obstacles and is included in the constrained category in completing the work smoothly (Nisa Islami 2018). The results of the descriptive data analysis of this study provide information that the quality assurance personnel experience difficulties or constraints in obtaining the needs of everything they need at work. This is evidenced by the responses recorded through the work motivation survey questionnaire with an average score of 3.40 . This score means that the needs of everything 
needed to complete the job are sometimes met and sometimes not. This condition is experienced by the quality assurance in the PTKIN environment based on the score given.

With regard to the amount of work that must be completed by quality assurance, it is often a problem in the smooth running of work. Based on the results of descriptive data analysis, it was found that information was found that the executor of the PTKIN quality assurance system often felt that the work completed was not commensurate with the award received. The award in question is the financial received, such as salary, job allowance, honorarium, and others. This can be proven through the responses submitted by the implementers of the quality assurance system through questionnaires with a score of 3.60. This score is in the category Often, which should be a certainty, or in reality it is

\section{Job Satisfaction Responses of the Quality Assurance System}

The response to job satisfaction of the implementers of the PTKIN quality assurance system was surveyed through five indicators, namely salary satisfaction, promotion satisfaction and, supervisory satisfaction, job satisfaction, and satisfaction always experienced with the same thing (certainly under the expected conditions).

The amount of reward (financial value) that must be received compared to the amount of work that must be completed should be balanced. Because this comparison will be felt by the implementer of the quality assurance system in completing their daily work. Regarding the appreciation that can be balanced with the amount of work to be a value that can foster a desire to work tough and strong. Implementers of the quality assurance system often feel a strong and resilient desire to work to get the job done. This is evidenced by the responses given through a score of 3.96 and being in the frequent category. This means that the implementer of the Quality Assurance System often grows in him wanting to work hard to complete a job that is his responsibility.

with friends. The number of questions on the job satisfaction variable is 10 questions that have gone through the validity and reliability of the instrument. The results of descriptive data analysis about job satisfaction of the implementers of the PTKIN quality assurance system can be illustrated with a circle diagram in Figure 2 below: 
Figure 2. Job Satisfaction Response of Guarantee Implementer

PTKIN quality

Figure 2 above is the result of the

4 There is a career effect on the job results analysis of shown

10

(ten)

question

items on the

job

satisfaction

variable, the

ten

questions on
JOB SATISFACTION

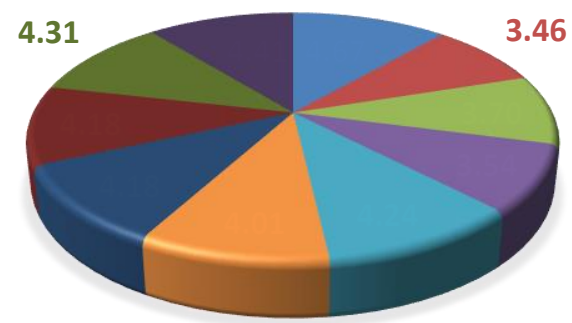

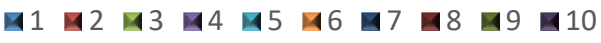

5 I always

enjoy getting work done

6 The work assigned according to the area of expertise the job satisfaction variable are as follows:

1 Receive Salary on time on a predetermined schedule

2 Receive honorarium / other financial additions in accordance with the job

3 Get the same opportunities and opportunities to improve work careers
7 Completion of work always involves work coordination

8 Supervision makes the job done quickly

9 Enjoy working with colleagues at work

10 Collaboration is needed in completing work

Figure 2 provides information that question number 1 regarding salary receipt 
for the implementer of the quality assurance system is on time as stipulated. This was responded by the quality assurance with an average score of 4.67. This score is the result of the average response that was responded to by 96 implementers of the PTKIN quality assurance system. The average score of 4.67 (5, if rounded) is the answer option score which states that the activity is always received on time on the salary payment system. Thus the salary payment system that is perceived by the quality assurance system has been running as it should be.

In question 2 (two) provides information about the existence of honoraria / other financial additions in accordance with the work being carried out, responded with an average score of 3.46. This means that quality underwriters sometimes get additional finance in addition to the base salary after completing work. Additional finance is understood not to be a routine obligation that must be accepted. Additional income such as additional fees from various academy activities and the amount cannot be predicted. But in the consideration of getting additional income is something that is tempting. Because additional income is not possible for everyone. This is because there are certain appraisers in accordance with the activities and fees that must be paid. Of course, those who get an honorarium other than salary will feel satisfied at work. Job satisfaction is not always present in quality assurance where he works. For example, regarding the career satisfaction he gets at work. The same opportunities and opportunities for advancing the careers of colleagues are very specific. Not all of them get the same opportunities to advance their careers, because of various conditions and situations at work. PTKIN guarantees provide responses through job satisfaction questionnaires that they sometimes get the same opportunities and opportunities in advancing careers at PTKIN. This response is evidenced by the score given of 3.70. This shows the problem of career advancement in PTKIN sometimes getting the same opportunities and opportunities. This means that not everyone has the opportunity to improve their career through work performance. Is work performance able to have an influence on career development for quality assurance in PTKIN. This answer was responded to by the quality assurance through a questioner by giving a score of 3.54. This means that sometimes work performance can affect the development and advancement of quality assurance careers. Thus, not everyone understands and accepts 
that a work career at PTKIN can be improved due to work performance. If this is the case, then what should be noted is that not everyone will want to have a career through the appointment of work performance. Not everyone wants to work hard for career success. So this is a challenge and an obstacle to make quality assurance workers able to work well to build a quality work system.

Job satisfaction is the feeling felt by someone in completing work which is associated with the rewards they can receive. This has an effect on the pleasure and displeasure of completing the work that has been assigned. Does the quality assurance at PTKIN always feel happy in completing work. This question was answered by the responses of the quality assurance through questionnaires that were distributed and assessed with a score of 4.24. That is, they often work to finish a job with pleasure. This needs to be emphasized in the category of always happy to complete work. If you are always happy in completing work, it means that you no longer cause problems at work, so that every time you feel happy to work, there will be job satisfaction.

Job satisfaction is very necessary at work. But sometimes the sense of job satisfaction disappears due to the many jobs given that do not match the skills and educational background they have. This is a problem at work. So job satisfaction is also influenced by such conditions. The current condition is that the PTKIN quality assurance officers are often assigned with jobs that are in accordance with their field of expertise. This can also be proven by the questionnaire score which responded to 4.01. Thus job satisfaction can be felt by often being given jobs that are in accordance with the area of expertise. In working, it also requires clear coordination with the person in charge of the work or fellow members who work together. Work coordination is also an important thing so that work can be completed properly. Sometimes the feeling of dissatisfaction with work is caused by a lack of work coordination and it is difficult for workers or work responsibilities. Current conditions, quality assurance at PTKIN often coordinates in completing the work assigned. This was revealed by information from their responses who gave a questionnaire score of 4.18. In completing work, they often coordinate with colleagues or with superiors who ask to complete a job. To work optimally, not only by coordinating. But supervision in completing work is also an important point that needs to be done. Sometimes people feel 
satisfied at work because of job supervision. On the contrary, people feel dissatisfied with work because they are always being watched. Currently, PTKIN quality assurance officers often get supervision at work. This was revealed from the answers to the survey questionnaire on job satisfaction by quality assurance which gave an average score of 4.18. This informs us that quality assurance often get supervision in completing a job. With these conditions they often feel satisfied through the supervision of their work.

Working well is not only happy because of the supervision at work. But some people feel happy working when there are colleagues who are always present at work. Some people want an atmosphere of being alone, lonely and focused at work. For some people is also not comfortable working when there is no friend beside him. What about the opinion of PTKIN quality assurance in this regard. Based on the results of descriptive data analysis, it provides information that quality assurance often and likes to work when there are friends in a work atmosphere.

\section{Performance of Quality Assurance System Implementers \\ The performance response of the implementers of the PTKIN quality}

This information is obtained from the quantitative data provided in filling out the quality assurance questionnaire which gives an average score of 4.31. This is often experienced by Penmu who feel job satisfaction when they work with coworkers.

Job satisfaction can also be generated through cooperation in completing work. Cooperation makes it easier to work a lot. By working together, you feel the ease in working. Complex jobs can be solved together with a work team. If the work is successful, you can feel a mutual success in completing the job. PTKIN quality assurance officers often collaborate with work teams in completing work. Because according to them, working together will create job satisfaction in completing work. This is evidenced by the results of descriptive data analysis through distributed questionnaires. The questionnaire responded with a score of 4.41 by the quality assurance. This score indicates that they often complete work by means of cooperation (cooperative) with the work team.

assurance system was surveyed through five indicators, namely Leadership, Innovators, Motivators, Learning on main tasks and 
functions, and community service. Each indicator developed several question items through the arrangement of a question item grid. The number of questions on the job satisfaction variable is 5 questions, all of which have been tested for the validity and reliability of the instrument. The results of descriptive data analysis about the performance of the PTKIN quality assurance system are illustrated through the circle diagram in Figure 3 below:

Figure 3. Diagram of the Performance Circle of the Aceh PTKIN SPM Implementers

\section{PERFORMANCE}

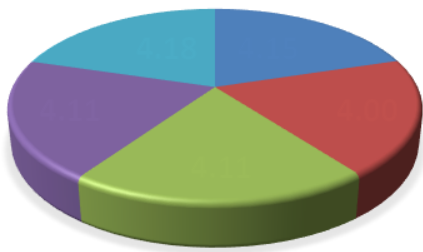

田1田2 日3 回45

Based on Figure 3 above is the result of an analysis of 5 (five)

1 Able to influence colleagues to achieve goals.

2 Have initiative in completing work.

3 Able to motivate team / coworkers.

4 Able to strengthen the quality system in teaching or structural assignments.

5 Able to strengthen quality through community service assignments.

Based on Figure 3 provides information that question number 1 about the quality assurance capacity of the Quality Assurance System to influence colleagues in achieving goals is often done. This treatment is a treatment that is usually born by a leader. Many people are not successful in completing work because they are not helped by work colleagues. This is because the person is not able to influence other people to want to work according to their wishes attitudes or behaviors like this are potential leadership abilities.

PTKIN quality assurance, quality assurance often and can influence colleagues to want to complete a job in accordance with the expected goals. This has been proven through the quality assurance response by 
giving a score of 4,15 . Thus, the results of descriptive analysis provide information that PTKIN quality assurance can often influence their friends to work to complete the work that has been determined. In addition to being able to influence friends to finish their work, PTKIN quality assurance also requires initiative in completing work. Many jobs are not completed on time because they do not have the courage to take a stand, or maybe the boss or person in charge of work is not there. So that the work cannot be completed on time. Meanwhile, good workers must be able to take the initiative in completing work. Regarding this matter, Quality assurance often takes the initiative to be able to complete a job on time. This is shown based on their responses in filling out the PTKIN quality assurance performance survey questionnaire. This response was given a score by Quality Assurance of 4.00. This indicates that quality assurance often takes the initiative to be able to work quickly and on target. PTKIN quality assurance must be able to motivate the work team so that the work is easily completed. Collaboration teams need work motivation so that they are enthusiastic and produce quality performance. PTKIN quality assurance often motivates work teams in rational ways, so that work can easily be completed. Motivation of the work team by quality assurance is often done, so as to influence strong work morale. Based on the results of descriptive data analysis, quality assurance often motivates work teams in the work completion process. This is evidenced by the quality assurance response by giving an average score of 4.11. This score, indicates that the motivation of the work team is often done in completing work.

The PTKIN quality assurance system needs to be improved through various means. For example, if a member of quality assurance is a quality assurance, then he needs to strengthen the quality assurance system through a learning process that is carried out (Lampuhyang et al. 2020). If he is a structural force, then he must also be able to strengthen the system through administrative tasks. Current conditions, PTKIN quality assurance officers often strengthen the internal quality assurance system in carrying out their duties and functions. This information is proven through the results of descriptive data analysis which responded by quality assurance with a score of 4.11. This means that mutual assurance often strengthens the quality assurance system through its tasks which ultimately have an 
impact on performance. Furthermore, the performance of quality assurance also needs to be shown through his service to the institution as a place where he works. So far, PTKIN quality assurance has provided and often provided services to institutions through work completion. This is evidenced by giving an average score of 4.18 for giving responses through a questionnaire that has been filled in as a quality assurance performance survey (Widyaningsih 2014).

From the results of descriptive data analysis of all the variables studied, namely work motivation, job satisfaction and PTKIN assurance performance, it can be described the comparison or tendency of the three variables studied, the trend of the three variables in question is shown in Figure 4 below:

Figure 4: Circle Diagram of Three Research Variables

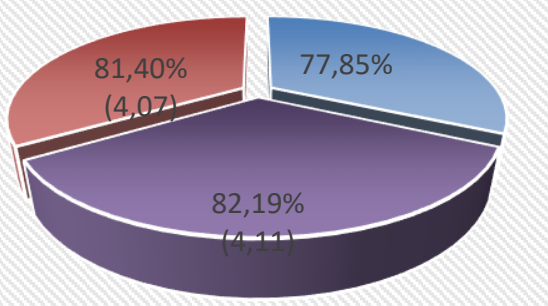

Motivasi Kerja $=77,85 \%$

Kepuasan Kerja $=82,19 \%$

Kinerja dosen $=81,40$

motivation that is responded to is 3.89 or the

From Figure 4 above, a description of the responses of each variable under study can be described. The results of descriptive data analysis, it was found that the quality assurance response of PTKIN to work motivation was at the $77.85 \%$ level of achievement. This informs that all responses related to the motivation variable are often carried out or occur in completing a worker. This is illustrated by the average score of work motivation of quality assurance is in the Strong category.

Likewise with regard to the job satisfaction variable which is given an average score by quality assurance is 4.11 , or $82.19 \%$. This provides information to us, where the quality assurance of PTKIN has responded to job satisfaction with a statement that they often feel job satisfaction in completing a job. In other words, the quality assurance response has resulted in job 
satisfaction in the strong category. While the response of PTKIN quality assurance often does all work related to efforts to improve quality assurance performance, therefore, quality assurance responds to performance issues by giving a score of 4.07 .

This shows that the performance of all activities related to performance often occurs in completing work. The results of this data analysis mean that the quality assurance performance of PTKIN has been in the strong category. This also becomes the government's accreditation system hope that PTKIN in Indonesia is expected to have an average grade of accreditation $\mathrm{A}$, in order to improve the quality of Islamic scholarship in Indonesia (Sulaiman and Wibowo 2016).

\section{Hypothesis test}

Hypothesis testing in this study was tested using Path Analysis statistics. Where testing is done by first compiling a hypothesis by making structural models. Where the structural models that appear in the hypothesis are obtained as follows:

Figure 5. Structure Model as a Research Conceptual

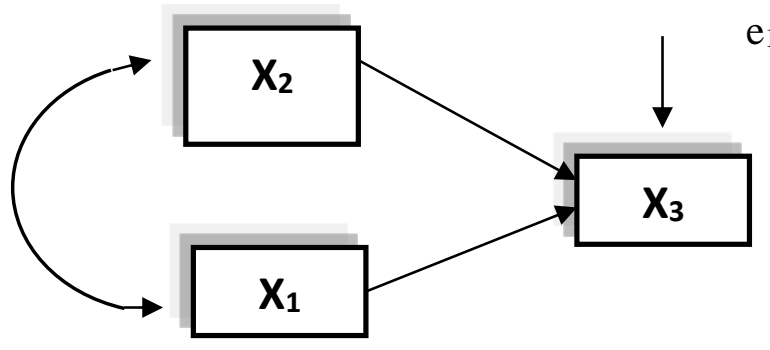

Notes:

$\mathrm{X}_{1}=$ Work Motivation

$\mathrm{X}_{2}=$ Job Satisfaction

$\mathrm{X}_{3}=$ QualityAssurance Performance

$\varepsilon_{1}=$ Epsilon 1

In Figure 5. above is a structural model which shows that the variable $X_{1}$ and the variable $\mathrm{X}_{2}$ are two exogenous variables. While the variable $\left(\mathrm{X}_{3}\right)$ is an endogenous variable. From the structural model image, it can provide an equation as follows (Yusaini 2020):

$\mathrm{X}_{3}=\mathrm{f}\left(\mathrm{X}_{1}, \mathrm{X}_{2}\right)$

So that the linear equation of the structure becomes:
$X_{3}=\rho X_{3} X_{1} X_{1}+\rho X_{3} X_{2} X_{2}+\rho \varepsilon_{1}$

From the structural model above, a statistical hypothesis can be tested with the following steps:

\section{Hypothesis;}

$H_{0}: \rho X_{3} X_{2-1}=0$; there is no influence together (simultaneously) motivation 
and job satisfaction on quality assurance performance.

Ha: $\rho X_{3} X_{2-1} \neq 0$; There is a joint (simultaneous) influence on motivation and job satisfaction on quality assurance performance.

The third hypothesis testing is to see whether or not there is an effect simultaneously, namely work motivation and job satisfaction on quality assurance performance in PTKIN. To take the necessity in testing this hypothesis is based on the results of the SPSS input in the Anova section, which is shown in table 2 below

Table 2. Anova Value of Motivation and Job Satisfaction Variables Against Quality Assurance Performance

\begin{tabular}{|c|c|c|c|c|c|c|}
\hline Model & & $\begin{array}{l}\text { Sum of } \\
\text { Squares }\end{array}$ & df & Mean Square & $\mathrm{F}$ & Sig. \\
\hline \multirow[t]{3}{*}{1} & Regression & 110,848 & 2 & 55,424 & 15,484 & ,000(a) \\
\hline & Residual & 332,891 & 93 & 3,579 & & \\
\hline & Total & 443,740 & 95 & & & \\
\hline
\end{tabular}

Based on table 2 above, it gives a value of Siq $(0.000)<0.05$, and this condition will reject the null hypothesis $(\mathrm{H} 0)$ and accept the alternative hypothesis (Ha). With the criteria for testing this hypothesis, it can be concluded that there is a positive and significant influence of motivation and job satisfaction variables simultaneously (simultaneously) on the performance of quality assurance in PTKIN. The results of the analysis show that motivation and job satisfaction provide a value of siq $<0.05$, where for work motivation $0.008<0.050$ and for job satisfaction $0.006<0.050$. Thus the two variables show a significant influence on the performance of PTKIN quality assurance. The results of this hypothesis test are highly relevant to Bambang Sumardjoko's research results, which explain that motivation and motivation are very influential and have a high impact on the quality assurance system (B Sumardjoko 2010). The results of this research hypothesis test are carried out with the results of previous studies conducted by Ida Nur Hidayati which concluded that job satisfaction has a positive effect on performance with a higher commitment to job satisfaction, then it will result in a high 
level of employee performance or quality assurance performance in higher education (Hidayati, Setiawan, and Solimun 2013). In determining how each variable can contribute to quality assurance performance, it can be analyzed through the determination of the linear regression structure equation that has been written previously formulated, it can be seen from the value of $B$ in the Unstandardized Coefficient section. Based on the anova value table, the constant a value is 7.507 , for the $b$ value for motivation $\left(X_{1}\right)$ is 0.163 and the $b$ value for job satisfaction $\left(\mathrm{X}_{2}\right)$ is 0.180 . By substituting the $\mathrm{a}$ and $\mathrm{b}$ values in the regression, a linear regression equation is obtained for the performance of PTKIN quality assurance, as follows (Riduwan 2009):

$\mathrm{Y}=\mathrm{a}+\mathrm{b} \mathrm{X}_{1}+\mathrm{bX}$

$Y=7,507+0,163 X_{1}+0,180 X_{2}$

From the regression equation above, it can be understood that the contribution of work motivation and job satisfaction to the performance of the PTKIN quality assurance system, that every time there is a change, increase or increase in the performance of the quality assurance system by $1 \%$, work motivation will contribute 0.163 and the contribution is balanced by satisfaction. work of 0.180 . This also often happens to other employees in Indonesia. So that these results provide an empirical proof that motivation and job satisfaction contribute to the implementation of the PTKIN Aceh quality assurance system (Komara and Nelliwati 2014).

\section{E. CONCLUSION}

The results of this article study concluded that the response of the Aceh PTKIN Quality Assurance to work motivation had been implemented with an achievement level of $77.85 \%$. This shows that all responses about work motivation often occur in completing a job. This is evidenced by the average score of motivation that is responded to is 3.89 (Strong Category). Work motivation of PTKIN Aceh quality assurance in implementing the guarantee system is Strong or Good. Furthermore, job satisfaction responded with an average score of 4.11 . This means that all activities related to job satisfaction have been carried out Good or strong. The results of quantitative data analysis give the conclusion that motivation and job satisfaction simultaneously have a positive and significant effect on the performance of the implementation of quality assurance in PTKIN Aceh.

\section{F. BIBLIOGRAPHY}


A Bacin. 2017. "Penjaminan Mutu Perguruan Tinggi : Dilema Politik Organisasi Dan UrgensI" 3: 215-22.

Amilin, Rosita Dewi. 2008. "Pengaruh Komitmen Organisasi Terhadap Kepuasan Kerja Akuntan Publik Debgan Role Stress Sebagai Variabel Moderating." Journal JAAI 12: 13-24. https://journal.uii.ac.id/index.php/JAAI /article/viewFile/38/135.

Basri, dkk. n.d. Renstra IAIN Langsa Periode 2015-2019. 2015th-2019th ed. Langsa, Aceh: IAIN Langsa.

Fitrah, Muh., . Ruslan, and . Hendra. 2018. "Urgensi Sistem Penjaminan Mutu Internal Terhadap Peningkatan Mutu Perguruan Tinggi." Jurnal Penjaminan $\begin{array}{llll}\text { Mutu } & 4 & \text { (1): } & 76 .\end{array}$ https://doi.org/10.25078/jpm.v4i1.400.

Fitria, R. dan Adam Idris., Aji Ratna Kusuma. 2014. "Pengaruh Remunerasi, Motivasi, Dan Kepuasan Kerja Terhadap Kinerja Pegawai/Tendik Di Kantor Pengadilan Tinggi Agama Samarinda." E-Journal Administrasi Reform 2: 1692-1704.

Gumiandar, Septi. 2013. "Komitmen Pimpinan Dalam Pelaksanaan Penjaminan Mutu Perguruan Tinggi (Studi Kasus IAIN Syekh Nurjati Cirebon)." Holistik 02 (02): 27-56. https://syekhnurjati.ac.id/jurnal/index.p hp/holistik/article/viewFile/447/393.

Hidayati, Ida Nur, Margono Setiawan, and Solimun. 2013. "Kecerdasan Emosional Dan Kecerdasan Spiritual Pengaruhnya Terhadap Kepuasan Kerja Dan Kinerja Karyawan Studi Di Lembaga Penjaminan Mutu Pendidikan (LPMP) Nusa Tenggara Barat." Jurnal Aplikasi Manajemen 11 (4): 629-39.

Jati Ariati. 2010. "Subjective Well-Being
(Kesejahteraan Subjektif) Dan Kepuasan Kerja Pada Staf Pengajar (Dosen) Di Lingkungan Fakultas Psikologi Universitas Diponegoro." Jurnal Psikologi Undip 8 (2): 117-23. https://doi.org/10.14710/jpu.8.2.117123.

Kementerian Agama R.I. 2015. "Peraturan Menteri Agama Republik Indonesia Nomor 10 Tahun 2015 Tentang Organisasi Dan Tata Kerja Institut Agama Islam Negeri Langsa." Institut Agama Islam Negeri Langsa. Kota Langsa. https: //doi.org/ 10.1145/ 3132847.3132886 .

Komara, Anton Tirta, and Euis Nelliwati. 2014. "Pengaruh Kompensasi, Motivasi Dan Kepuasan Kerja Terhadap Kinerja Pegawai Negeri Sipil (PNS) Di Lingkungan Rumah Sakit Umum Daerah (RSUD) Kota Bandung." Jurnal Ekonomi, Bisnis \& Entrepreneurship 8 (2): 73-85. http://jurnal.stiepas.ac.id/ index.php/jebe/article/view/40.

Kreitner, R., Angelo Kinicki. 2014. Perilaku Lembaga (Organizational Behavior). 9th ed. Jakarta: Salemba Empat.

Kurniawan, agung widhi. 2012. "Pengaruh Kepemimpinan Dan Pengembangan Sumber Daya Manusia Terhadap Kepuasan Kerja, Motivasi Kerja, Dan Kinerja Karyawan BANK Sulselbar." Ekonomi Dan Keuangan 16 (80): 391408.

Lampuhyang, Jurnal, Lembaga Penjaminan Mutu, Stkip Agama, and Hindu Amlapura. 2020. "Pemanfaatan Teknologi Informasi Dalam Pembelajaran Tingkat Sekolah Dasar Pada Masa Pandemi Covid-19." Https://E-Journal.StkipAmlapura.Ac.Id/Index.Php/Jurnallamp uhyang 11 (2): 13-25. 
Lumentut, GF, JT Pantow, and Dkk. 2017. "Pola Komunikasi Pemimpin Organisasi Dalam Meningkatkan Motivasi Kerja Anggota Di LPM (Lembaga Pers Mahasiswa) Inovasi UNSRAT.” E-Journal “Acta Diurna” 6 (1): $1-15$.

Ma'ruf, Hidayat, and Salafuddin Fitri. 2021. "Performance and Work Motivation of Honorary Teachers in Isolated Village (Case Study in Mis Ulupus Sa'Adah Hulu Sungai Utara)." Edukasi Islami: Jurnal Pendidikan Islam 10 (01): 363. https://doi.org/10.30868/ei.v10i01.972.

Mala, Abdurrahman, and Munirah Munirah. 2019. "Organizational Culture and Quality of Services at IAIN Sultan Amai Gorontalo." Al-Ulum 19 (2): 421-42. https://doi.org/10.30603/au.v19i2.928.

Marwan. 2015. "Pengaruh Budaya Lembaga, Perilaku Kepemimpinan, Motivasi Berprestasi, Melalui Kepuasan Kerja Terhadap Kinerja Dosen Perguruan Tinggi Swasta Di Provinsi Aceh." UNIMED Medan.

Nasution, Robby Darwis. 2015. "Meneropong Masa Depan Pendidikan Di Indonesia (Penerapan Virtual Learning Di Indonesia)." Prosiding Seminar Nasional Pendidikan, no. November: 489-97.

Nisa Islami. 2018. "Manajemen Teknis Akreditasi Institusi Unggul Bagi Perguruan Tinggi Keagamaan Islam Negeri (PTKIN).” Jurnal Tawadhu 2 (2): 588-610.

Pramudyo, A. 2010. “Analisis Faktor-Faktor Yang Mempengaruhi Kinerja Dosen Negeri Pada Kopertis Wilayah V Yogyakarta.” Jurnal JBTI 1: 5-11.

Presiden Republik Indonesia. 2012. "Undang-Undang Republik Indonesia
Nomor 12 Tahun 2012 Tentang Pendidikan Tinggi." Jakarta.

Ridho, Muhammad, and Febsri Susanti. 2019. "Pengaruh Stres Kerja Dan Motivasi Kerja Terhadap Kepuasan Kerja Pada Karyawan Bank Mandiri Syariah Cabang Padang." https://doi.org/10.31227/osf.io/pa2cg.

Riduwan. 2009. Skala Pengukuran VariabelVariabel Penelitian. Bandung: Alfabeta.

Robbins, S.P., Mary Coulter. 2010. Manajemen. Sepuluh. Jakarta: Erlangga.

Singarimbun, M., Sofian Efendi. 1989. Metode Penelitian Survai. Jakarta: LP3ES.

Sulaiman, Ahmad, and Udik Budi Wibowo. 2016. "Implementasi Sistem Penjaminan Mutu Internal Sebagai Upaya Meningkatkan Mutu Pendidikan Di Universitas Gadjah Mada." Jurnal Akuntabilitas Manajemen Pendidikan 4 (1):

17. https://doi.org/10.21831/amp.v4i1.8197

Sumardjoko, B. 2010. "Faktor-Faktor Determinan Peran Dosen Dalam Penjaminan Mutu Perguruan Tinggi." Jurnal Cakrawala Pendidikan 29: 294309.

Sumardjoko, Bambang. 2010. "FaktorFaktor Determinan Peran Dosen Dalam Penjaminan Mutu Perguruan Tinggi." Jurnal Cakrawala Pendidikan 3 (3): 294-310. https://doi.org/10.21831/cp.v3i3.359.

Widyaningsih, Pipin. 2014. "Desain Aplikasi Knowledge Management System Untuk Mendukung Kinerja Lembaga Penjaminan Mutu Perguruan Tinggi Menggunakan Pendekatan User Centered Design (Studi Kasus LPJM 
Edukasi Islami: Jurnal Pendidikan Islam, VOL: 10/NO: 01 Februari 2021

STMIK Duta Bangsa Surakarta)." Jurnal Duta.Com. 7 (2): 15-35.

yusaini. 2018. "Pengaruh Budaya Organisasi, Kepemimpinan, Kepuasan Kerja Dan Komitmen Organisasi Terhadap Kinerja Dosen PTKIN Aceh." Universitas Negeri Medan.

Yusaini. 2020. "Kontribusi Budaya, Kepemimpinan, Kepuasan Kerja, Dan Komitmen Dalam Peningkatan Kinerja Dosen." Jurnal Nidhomul Haq 5 (1): 32-45. 
Edukasi Islami: Jurnal Pendidikan Islam, VOL: 10/NO: 01 Februari 2021

P-ISSN: 2614-4018

DOI : 10.30868/ei.v10i01.1426

E-ISSN: 2614-8846 